\title{
Effect of inhibition of increased gonadotrophin secretion before 20 weeks of age in bull calves on testicular development
}

\author{
R. K. Chandolia, A. C. O. Evans* and N. C. Rawlings ${ }^{\dagger}$ \\ Department of Veterinary Physiological Sciences, University of Saskatchewan, 52 Campus drive, \\ Saskatoon, SK, Canada S7N 5B4
}

\begin{abstract}
In bull calves serum concentrations of $\mathrm{LH}, \mathrm{FSH}$, and to a lesser extent testosterone, are increased transiently, between 6 and 20 weeks of age. The function of gonadotrophin and testosterone secretion in this period of growth and development was tested by injecting five Hereford bull calves with a GnRH agonist (15 mg Leuprolide acetate) i.m. at 6, 10 and 14 weeks of age; five vehicle treated calves acted as controls. On the basis of blood samples taken every $15 \mathrm{~min}$ for $10 \mathrm{~h}$, at 12 weeks of age, mean serum concentrations of LH, FSH and testosterone and LH and FSH pulse frequency and amplitude were decreased $(P<0.05)$ by Leuprolide acetate. At 24 weeks of age, mean serum concentrations of LH, and LH and FSH pulse frequency in Leuprolide acetate treated calves exceeded $(P<0.05)$ that seen in control calves. On the basis of blood samples taken every other week, treatment with Leuprolide acetate decreased mean serum concentrations of FSH and testosterone at 14, 16 and 18 weeks of age compared with control calves and delayed the peak of the early increase in LH secretion from 20 to 24 weeks of age $(P<0.05)$. Scrotal circumference between 22 and 50 weeks of age, pixel units from ultrasound images of the testes, testis mass at castration at 50 weeks of age, and numbers of spermatids and pachytene spermatocytes were all lower in Leuprolide treated calves than in controls. A transient increase in secretion of LH, FSH and testosterone in young bull calves before 20 weeks of age may, therefore, be a critical step in the initiation and timing of testicular development in bull calves.
\end{abstract}

\section{Introduction}

Puberty in bull calves can be defined as the time at which an ejaculate contains $5 \times 10^{7}$ spermatozoa with at least $10 \%$ motility (Wolf et al., 1965); this occurs at a scrotal circumference of approximately $28 \mathrm{~cm}$ (Lunstra $\mathrm{et} \mathrm{al.,} \mathrm{1978).} \mathrm{In} \mathrm{previous}$ studies, in Hereford bull calves, puberty occurred at about 38 weeks of age (ranging between 35 and 43 weeks of age), at a body mass of $294 \mathrm{~kg}$ (Evans et al., 1993).

In Hereford bull calves, a transient increase in gonadotrophin secretion occurs between 6 and 20 weeks of age (Evans et al., 1993; Rawlings and Evans, 1995), just before the initiation of testicular development. This early increase in LH and FSH secretion is largely a reflection of an increase in LH and FSH pulse frequency; the rise in LH secretion is generally more pronounced than the rise in FSH secretion (Evans et al., 1993). This early change in gonadotrophin secretion is also seen in other breeds of bull calf (Rawlings et al., 1972; Rawlings et al., 1978; Deaver and Peters, 1988; Miyamoto et al., 1989). Increased LH and FSH secretion in young bull calves is followed by an increase in testosterone production; however,

\footnotetext{
*Present address: Department of Veterinary Physiology, Cornell University, Ithaca, New York 14853-6401, USA.

'Correspondence.

Received 29 April 1996
}

this early increase in testosterone secretion is minimal compared with the large increase occurring at puberty (Amann and Walker, 1983; Amann et al., 1986). Similar developmental changes in gonadotrophin and testosterone secretion have been reported early in the postnatal period in rats and rams (Wilson and Lapwood, 1979; Kolho et al., 1987). It has been suggested that this early increase in secretion of gonadotrophins in young bull calves may be critical for testicular development and reproductive maturation (Deaver $e$ t al., 1988; Evans et al., 1993). The early increase in gonadotrophin secretion is associated with the initiation of spermatogenesis, just before tubule lumination and as the Sertoli cells and Leydig cells are differentiated (Curtis and Amann, 1981; Evans et al., 1995). In a previous study, calves with the highest peak of serum concentration of LH, during the period from 6 to 20 weeks of age, reached sexual maturity earlier than those with lower serum LH concentrations (Evans et al., 1995). Elimination of pulsatile LH secretion from 7.5 to 24 weeks of age by oestradiol release from implants resulted in a lower testis mass at 24 weeks of age (Deaver et al., 1988).

The objectives of the present investigation were to study the involvement of the early rise in gonadotrophin secretion on testicular and endocrine development in bull calves. This was tested by suppressing the early rise in gonadotrophin secretion with a GnRH agonist. 


\section{Materials and Methods}

\section{Animals and experimental period}

Ten spring-born, age and weight matched ( \pm 5 days) Hereford bull calves were kept on pasture with their mothers until 25 weeks of age; they were then weaned and kept in a corral and fed a ration of $21 \%$ ground barley, $51 \%$ ground hay, $22 \%$ ground straw and $0.005 \%$ of a $1: 1$ calcium:phosphorus mineral mix $(\mathrm{w}: \mathrm{w})$ ad libitum, with brome alfalfa hay and water freely available.

At 6,10 and 14 weeks of age, five calves received $15 \mathrm{mg}$ GnRH agonist, i.m., in a slow release formulation (Leuprolide acetate: Lupron depot. TAP Pharmaceuticals Inc., Deerfield, IL) suspended in $3 \mathrm{ml}$ of a solution of $0.5 \%(\mathrm{w} / \mathrm{v})$ sodium carboxymethylcellulose, $5 \%(\mathrm{w} / \mathrm{v})$ D-mannitol and $0.1 \%(\mathrm{w} / \mathrm{v})$ polysorbate 80 in water. Control bull calves $(n=5)$ received vehicle only. The dose was based on a previous experiment in heifers of the same breed (Evans and Rawlings, 1994). Leuprolide acetate is a synthetic GnRH agonist with D-leucine substituted at position 6 and an ethylamide residue substituted at position 10, and is encapsulated in microspheres for slow release. The release of Leuprolide acetate occurs for at least 4 weeks after injection (Filicori and Flamigni, 1988). It was projected that the treatment with Leuprolide acetate would decrease LH secretion over the period in which the early increase in LH secretion was seen in young bull calves ( $6-20$ weeks old). Blood samples were taken every hour for $6 \mathrm{~h}$, then every $6 \mathrm{~h}$ for the next $36 \mathrm{~h}$ and finally every $12 \mathrm{~h}$ for a further $72 \mathrm{~h}$, after each injection of Leuprolide acetate. At 12 weeks (during treatments) and 24 weeks (after treatments had been completed) of age, blood samples were taken every $15 \mathrm{~min}$ for $10 \mathrm{~h}$. One day before intensive blood sampling, calves were catheterized (vinyl tubing SV-70; internal and external diameter 1.0 and $1.5 \mathrm{~mm}$, respectively; Dural Plastics and Engineering, Dural, NSW). During sampling, calves were housed in pens in a barn with their mothers; the cows were haltered. The first sample was taken at 08:00 h, and sampling continued until 18:00 h. Blood samples were also taken every other week by jugular venepuncture. Blood samples were allowed to clot for 12-18 h at room temperature and then centrifuged at $1500 \mathrm{~g}$ for $15 \mathrm{~min}$. Serum was poured off and stored at $-20^{\circ} \mathrm{C}$ until analysed.

Body mass was recorded every month from 2 weeks of age, but scrotal circumference was measured only every two weeks from 22 weeks of age to cover the period of rapid testicular growth (MacMillan and Hafs, 1969). At 50 weeks of age, immediately before castration, ultrasound images of both testes were taken in longitudinal and transverse planes as described by Pechman and Eilts (1987). The pixel intensity of the ultrasound images was recorded as described by Pierson and Adams (1995). In brief, a Sun Sparc computer station 10 (Sun microsystems, Mt. View, CA) was used to measure pixel units on the ultrasound images (grey-scale value of individual picture elements ranging from 0 to 255 , where 0 is black and 255 white), using custom developed computer algorithms (SYNERGYNE I ${ }^{\circ}$, R. A. Pierson, Department of Obstetrics and Gynaecology, University of Saskatchewan, Saskatoon, SK). Animals were castrated at 50 weeks of age, so that they were castrated after the achievement of puberty (puberty was defined as the time at which scrotal circumference most closely approximated $28 \mathrm{~cm}$; Lunstra et al., 1978). In previous studies in beef bull calves, puberty occurred at between 38 and 43 weeks of age.

\section{Tissue processing}

Testes were weighed and pieces of testes were fixed in Bouin's solution for histological evaluation. Tissue was embedded in paraffin wax and sections $5 \mu \mathrm{m}$ thick were stained with haematoxylin and eosin. Representative cells (elongated and round spermatids, pachytene spermatocytes, $\mathrm{A}$ and $\mathrm{B}$ spermatogonia and Sertoli cells) were counted in stage VI of spermatogenesis as described by Curtis and Amann (1981). This stage corresponds to stage VII in rats and is considered the most sensitive to hormone changes (Russel and Clermont, 1977). The counts were corrected for section thickness and nuclear diameter of cells (Abercrombie, 1946). Testicular germ cells were also sorted on the basis of DNA content by flow cytometry as reported by Arvindan et al. (1990) and Medhamurthy et al. (1993). In brief, approximately $150 \mathrm{mg}$ of testicular tissue was minced in $3 \mathrm{ml}$ Dulbecco's phosphatebuffered saline (D-PBS), vortexed and washed in D-PBS $(\mathrm{pH} 7.4)$ and treated with $0.5 \%(\mathrm{w} / \mathrm{v})$ pepsin (Serrafein Biochemica, Heidelberg) at $\mathrm{pH} 2.0$ for $\mathrm{Ih}$ at $37^{\circ} \mathrm{C}$. After centrifugation at $800 \mathrm{~g}$ for $10 \mathrm{~min}$, the cells were resuspended in a staining solution containing $25 \mu \mathrm{g}$ ethidium bromide $\mathrm{ml}^{-1}$ (Sigma Chemical Co., St Louis, MO), $40 \mu \mathrm{g}$ ribonuclease A $\mathrm{ml}^{-1}$ (Sigma) and $0.3 \%(\mathrm{w} / \mathrm{v})$ Nonidet P-40 (Sigma) in D-PBS for $20 \mathrm{~min}$ at $4^{\circ} \mathrm{C}$. After adding $0.5 \mathrm{ml}$ Facsflow solution, about 10000 cells were analysed using a Facsort flow cytometer (Becton Dickinson, Mississauga, Ontario) (Medhamurthy et al., 1993). The cells were sorted on the basis of DNA content in the sequence: (a) haploid cells (elongated spermatids followed by round spermatids), (b) diploid DNA-containing cells (for example, GI-spermatogonia, G1-Leydig cells, G1-Sertoli cells) and (c) other cells, including cells during mitotic or primary meiotic division, after DNA synthesis but before cell division (for example, leptotene, zygotene, pachytene and diplotene primary spermatocytes; spermatogonial and non-germinal cells during the G2-phase of the cell cycle) (Chandolia et al., 1991; Toppari et al., 1989).

\section{Radioimmunoassays}

Serum concentrations of $\mathrm{LH}$ and FSH were determined in double antibody radioimmunoassays (Rawlings and Evans, 1995). The first antibody used for the FSH assay was NIDDKanti-oFSH-1, and concentrations are expressed in terms of USDA-bFSH-II. The sensitivity of the assay, assessed as the lowest concentration of FSH capable of significantly displacing labelled FSH from the antibody (' $\mathrm{f}$ ' test), was $0.13 \mathrm{ng} \mathrm{ml}{ }^{-1}$. The intra- and interassay coefficients of variation (CV) were $8.6 \%$ and $12.8 \%$, or $6.8 \%$ and $8.4 \%$, respectively, for sera with mean FSH concentrations of 1.28 or $3.08 \mathrm{ng} \mathrm{ml}^{-1}$, respectively. The CVs were compiled by replicating reference sera in each assay. $\mathrm{LH}$ concentrations are expressed in terms of NIDDK-bLH4. The sensitivity of the assay was $0.07 \mathrm{ng} \mathrm{ml}^{-1}$. The intra- and interassay CVs were $9.5 \%$ and $14.9 \%$, or $6.0 \%$ and $12.4 \%$, respectively for reference sera with mean $\mathrm{LH}$ concentrations of 0.29 or $0.87 \mathrm{ng} \mathrm{ml}^{-1}$, respectively. 

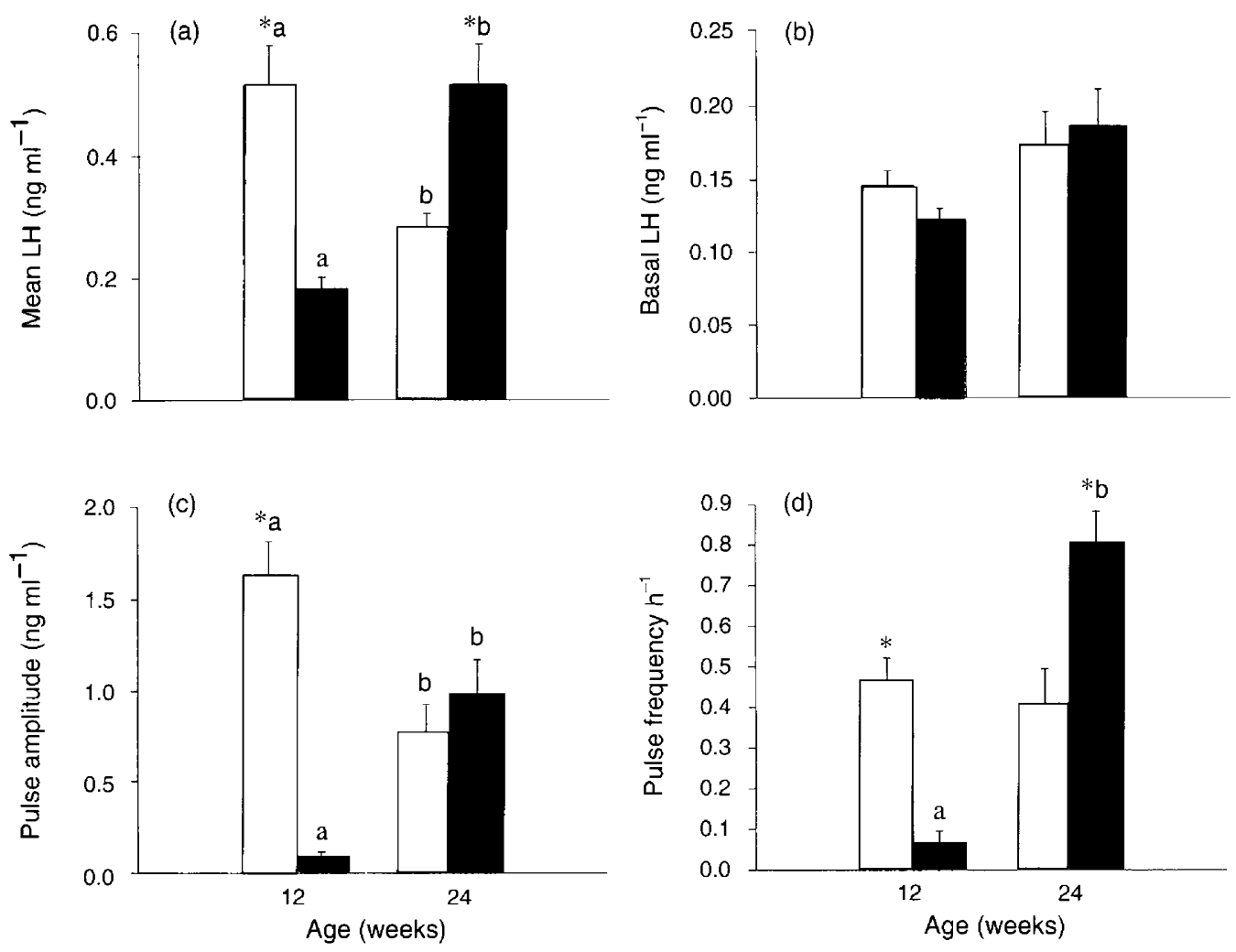

Fig. 1. Mean (a) and basal (b) serum concentrations of LH, and LH pulse amplitude (c) and frequency (d) (mean \pm SEM) at 12 and 24 weeks of age in Hereford bull calves treated with vehicle (control: $\square$ ) or Leuprolide acetate $(\boldsymbol{\square})$ at 6,10 and 14 weeks of age. Blood samples were taken every $15 \mathrm{~min}$ for $10 \mathrm{~h}$. Values with different superscripts show differences between ages within treatment groups $(P<0.05)$. Asterisks show significant differences $(P<0.05)$ between treatment and control.

Serum concentrations of testosterone were measured by radioimmunoassay (Rawlings and Evans, 1995). The sensitivity of the assay was $0.07 \mathrm{nmol} \mathrm{I}^{-1}$. The intra- and interassay $\mathrm{CVs}$ were $8.0 \%$ and $10.4 \%$ or $6.5 \%$ and $9.4 \%$, respectively, for reference sera with mean testosterone concentrations of 4.57 or $8.88 \mathrm{nmol} \mathrm{I}^{-1}$

\section{Statistical analysis}

The PC-pulsar programme (J. Gitzen and V. Ramirez, University of Illinois, IL) was used to analyse the episodic patterns of serum concentrations of LH and FSH in blood samples collected every $15 \mathrm{~min}$ for $10 \mathrm{~h}$. From this analysis, basal and mean serum concentrations, pulse amplitude and frequency were recorded. Pulses were identified using standard deviation criteria of height ( $G$ values) and duration (Merriam and Wachter, 1982). Basal concentrations were determined by subtraction of the pulses from the $10 \mathrm{~h}$ gonadotrophin profiles.

Data for scrotal circumference, body mass, basal and mean serum concentrations of $\mathrm{LH}$ and $\mathrm{FSH}$, and $\mathrm{LH}$ and $\mathrm{FSH}$ pulse amplitude and frequency were analysed for the effect of treatment, age and interactions using univariate and multivariate repeated measures analysis of variance (ANOVA, True Epistat ${ }^{\mathrm{R}}$, Epistat Services, Richardson, TX). If the main effects were significant, multiple comparisons were made using the method of Tukey (honestly significant difference) for
post-ANOVA multiple comparisons $(P<0.05)$. Pixel units, testis mass at castration, age at puberty and corrected numbers of testicular cells were compared by one-way analysis of variance $(P<0.05)$. Data are presented as means \pm SEM.

\section{Results}

\section{Hormonal responses}

The administration of Leuprolide acetate at 6 weeks of age caused a transient increase in serum LH concentrations lasting $4 \mathrm{~h}$. Subsequent injections at 10 and 14 weeks of age did not result in a significant increase in serum concentrations of $\mathrm{LH}$ $(P>0.05)$

In blood samples collected every $15 \mathrm{~min}$ for $10 \mathrm{~h}$, at 12 weeks of age, in the middle of the treatment period, mean serum LH concentrations, and LH pulse frequency and amplitude were all lower in calves treated with Leuprolide acetate than in control calves. However, at 24 weeks of age, after treatment was completed, values for the same parameters had all significantly increased in the treated calves and mean serum concentrations of $\mathrm{LH}$ and LH pulse frequency were higher in treated calves than in controls $(P<0.05$; Fig. 1$)$. Mean serum concentrations of $\mathrm{LH}$ and $\mathrm{LH}$ pulse amplitude in control calves were higher at 12 weeks of age than at 24 weeks of age $(P<0.05$; Fig. 1). 

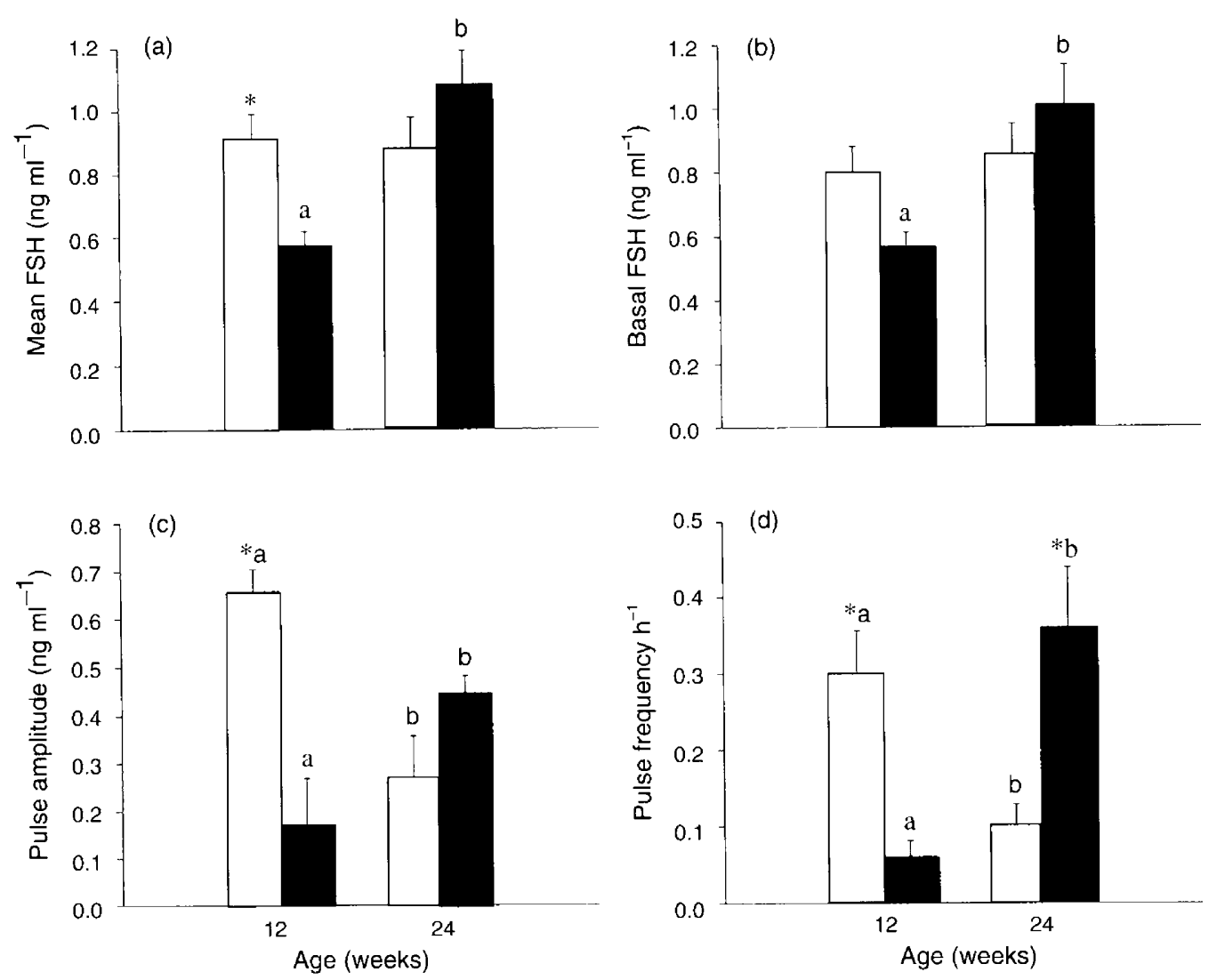

Fig. 2. Mean (a) and basal (b) serum concentrations of FSH, and FSH pulse amplitude (c) and frequency (d) (mean \pm SEM) at 12 and 24 weeks of age in Hereford bull calves treated with vehicle (control: $\square$ ) or Leuprolide acetate ( $)$ at 6, 10 and 14 weeks of age. Blood samples were taken every $15 \mathrm{~min}$ for $10 \mathrm{~h}$. Values with different superscripts show differences between ages within treatment groups $(P<0.05)$. Asterisks show significant differences $(P<0.05)$ between treatment and control.

In blood samples collected every $15 \mathrm{~min}$ for $10 \mathrm{~h}$, mean serum FSH concentrations, and FSH pulse amplitude and pulse frequency were lower in Leuprolide acetate treated calves than in control calves at 12 weeks of age $(P<0.05$; Fig. 2). Mean and basal serum concentrations of FSH, and FSH pulse frequency and amplitude were all higher at 24 weeks of age than at 12 weeks of age in calves treated with Leuprolide acetate; this trend was not seen in control calves $(P<0.05$; Fig. 2$)$. In control calves, FSH pulse frequency and amplitude were lower at 24 weeks of age than at 12 weeks of age, and at 24 weeks of age, pulse frequency in control calves was lower than in treated calves $(P<0.05)$.

Mean serum testosterone concentrations in calves treated with Leuprolide acetate appeared lower than in control calves at 12 weeks of age $\left(0.14 \pm 0.04\right.$ versus $1.25 \pm 0.14 \mathrm{nmol} \mathrm{l}^{-1}$; $P<0.17)$ but not at 24 weeks of age $(2.15 \pm 0.17$ versus $\left.2.02 \pm 0.31 \mathrm{nmol} \mathrm{l}^{-1} ; P>0.05\right)$. On the basis of blood samples taken every 2 weeks, treatment with Leuprolide acetate delayed the peak in the early increase in LH secretion from 20 to 24 weeks of age $(P<0.05)$ compared with control calves $(P<0.05$; Fig. 3). Serum concentrations of FSH and testosterone in calves treated with Leuprolide acetate were lower than in controls at 14,16 and 18 weeks of age; FSH was also lower at 26 weeks of age $(P<0.05$; Fig. 3$)$.

\section{Body mass and testicular traits}

Body mass did not differ between the two groups $(P>0.05)$, but scrotal circumference was lower $(P<0.05)$ at all times of measurement in the calves treated with Leuprolide acetate than in the control calves (22-50 weeks of age) (Fig. 4). The paired testes mass at castration, at 50 weeks of age, was significantly lower in calves treated with Leuprolide acetate than in control calves $(313.3 \pm 11.0$ versus $388.4 \pm 25.3 \mathrm{~g} ; P<0.05)$. Timing of puberty based on a scrotal circumference of $28 \mathrm{~cm}$ (Lunstra et al., 1978) was $42 \pm 1.2$ weeks of age for control calves and $47 \pm 0.7$ weeks of age for calves treated with Leuprolide acetate $(P<0.05)$. On the basis of histological examination of testis sections, in stage VI of spermatogenesis, the number of elongated and round spermatids and pachytene spermatocytes was significantly lower $(P<0.05)$ in calves treated with Leuprolide acetate than in control calves (Fig. 5). Analysis of testicular germ cells by flow cytometry showed a lower $(P<0.05)$ percentage of elongated spermatids in calves treated with Leuprolide acetate $(2.40 \pm 0.20 \%)$ than in control calves $(3.86 \pm 0.23 \%)$. The overall percentages of round spermatids (18.4 $\pm 2.1 \%$ versus $22.0 \pm 3.1 \%)$, diploid cells $(26.6 \pm 1.6 \%$ versus $26.4 \pm 1.0 \%$ ) and other cells (cells in mitotic or primary meiotic division following DNA synthesis but before cell 

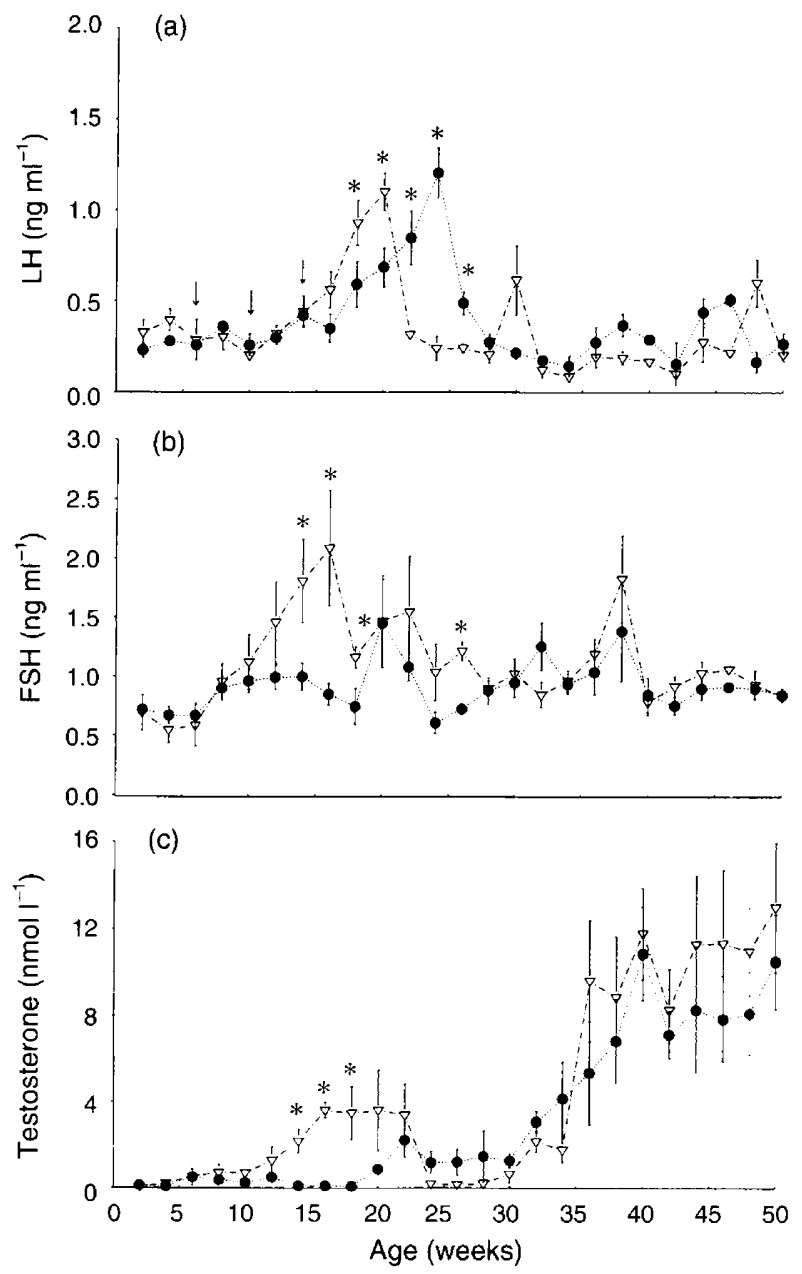

Fig. 3. Mean serum concentrations of (a) LH, (b) FSH and (c) testosterone (mean \pm SEM) in blood samples taken every other week from 2 to 46 weeks of age in Hereford bull calves treated with vehicle (control: $\nabla$ ) or Leuprolide acetate $(-)$ at 6,10 and 14 weeks of age (arrows). Asterisks show significant differences $(P<0.05)$ between treatment and control.

division) $(53.8 \pm 3.2 \%$ versus $49.3 \pm 4.3 \%)$ did not differ significantly $(P>0.05)$ between calves treated with Leuprolide acetate and control calves.

Pixel units for the left testis in longitudinal (129.0 \pm 0.47 versus $158.4 \pm 1.27)$ and transverse ( $135.7 \pm 0.70$ versus $157.7 \pm 1.20)$ planes and for the right testis in longitudinal (131.0 \pm 0.45 versus $162.1 \pm 1.12)$ and transverse (134.4 \pm 0.71 versus $155.8 \pm 1.49$ ) planes were lower for calves treated with Leuprolide acetate compared with control calves, respectively $(P<0.05)$.

\section{Discussion}

In young bull calves there is a transient increase in gonadotrophin secretion between 6 and 20 weeks of age (Pechman and Eilts, 1987; Deaver and Peters, 1988; Evans et al., 1993; Rawlings and Evans, 1995). Serum concentrations of LH generally reach a peak between 6 and 16 weeks of age, but there is always considerable variation in the timing of this peak
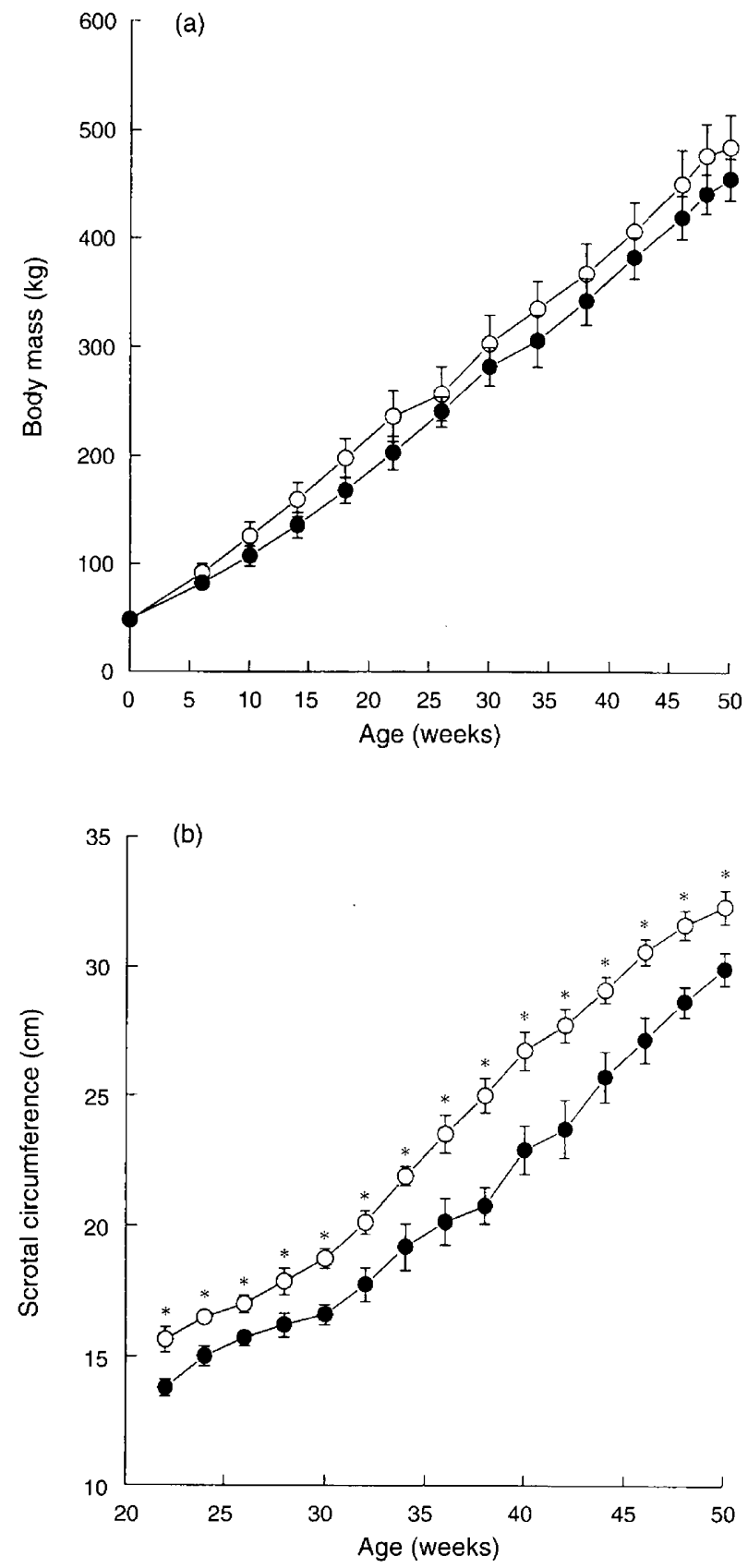

Fig. 4. (a) Body mass (2-50 weeks of age) and (b) scrotal circumference (22-50 weeks of age; mean \pm SEM) of Hereford bull calves treated with vehicle (control: $O$ ) or Leuprolide acetate $(O)$ at 6,10 and 14 weeks of age. Asterisks show significant differences $(P<0.05)$ between treatment and control.

among animals (Evans et al., 1993, 1995; Rawlings and Evans, 1995). In the present study, Leuprolide acetate was given at 6 , 10 and 14 weeks of age. Leuprolide acetate causes a decrease in gonadotrophin secretion for at least 4 weeks after administration (Watanabe et al., 1992). Therefore, we hoped to decrease LH and FSH secretion from 6 weeks to at least 18 weeks of age, the bulk of the period of the early rise in the secretion of these two hormones, based on previous studies. On the basis of blood samples taken every $15 \mathrm{~min}$ for $10 \mathrm{~h}$ at 12 weeks of age, it appeared that Leuprolide acetate treatment 

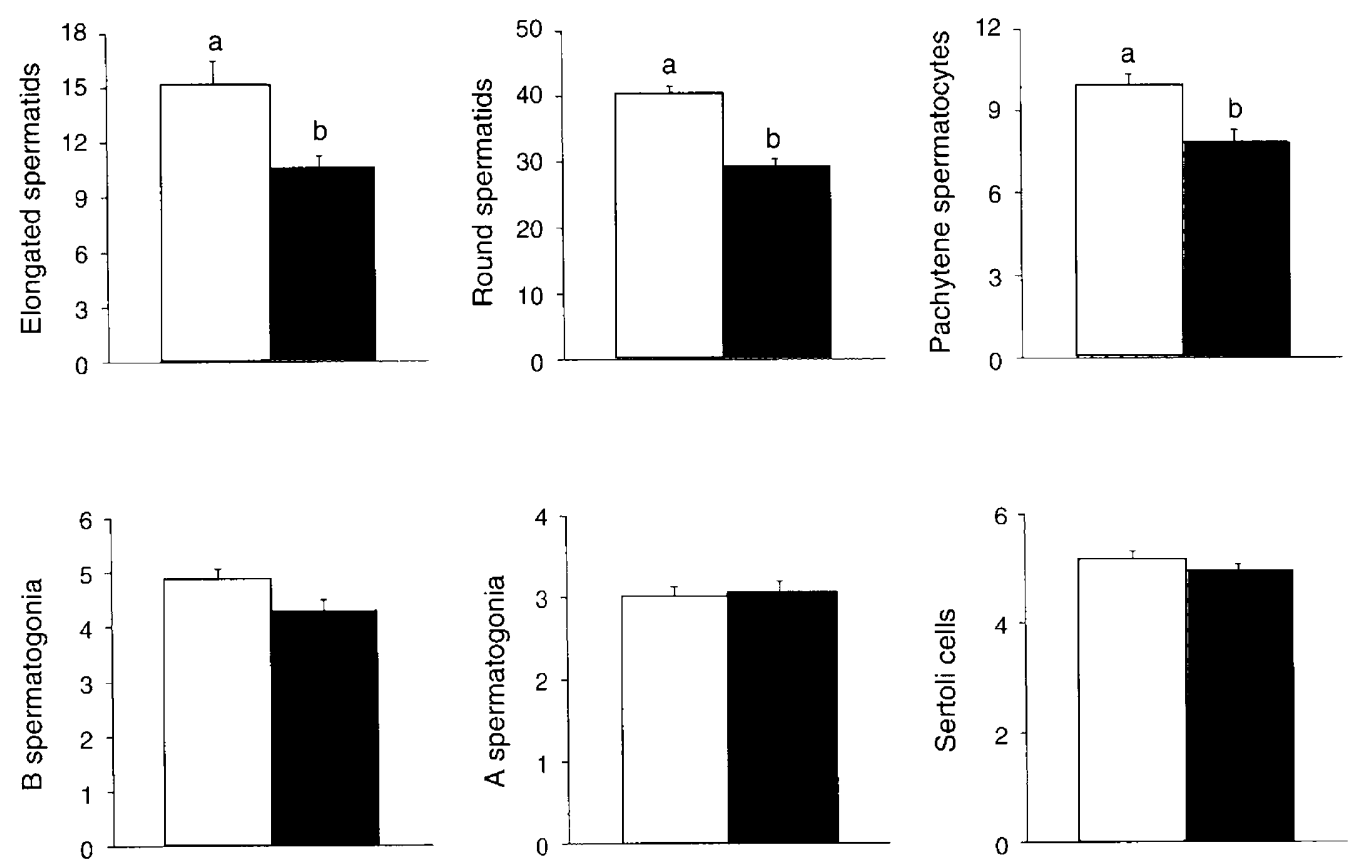

Fig. 5. Mean ( \pm SEM) numbers of germ cells and Sertoli cells per tubule cross-section, for tubules in stage VI of spermatogenesis at 50 weeks of age, in control $(\square)$ and Leuprolide treated $(\boldsymbol{\square})$ Hereford bull calves. Values with different superscripts are significantly different $(P<0.05)$.

was very effective in reducing pulsatile but not basal secretion of both LH and FSH. Pulsatile secretion of LH and FSH recovered by 24 weeks of age and showed some evidence of a rebound to greater values than in control calves.

On the basis of blood samples taken every other week, it appeared that the early increases in FSH and testosterone secretion were largely blocked by treatment with Leuprolide acetate. The early rise in $\mathrm{LH}$ secretion was not blocked but delayed by treatment with Leuprolide acetate, with its peak occurring 4 weeks later than in control calves. The delay in the early rise in LH secretion seen in calves treated with Leuprolide acetate, coupled with decreased FSH and testosterone secretion before they reached 24 weeks of age, decreased subsequent testicular growth and decreased or delayed spermatogenesis and delayed puberty (scrotal circumference of $28 \mathrm{~cm}$; Lunstra et al., 1978). In a previous study, treatment of bull calves with implants releasing oestradiol from 7.5 weeks to 24 weeks of age eliminated LH pulses and reduced testis size at 24 weeks of age (Deaver et al., 1988). In previous studies, we have also seen that bull calves with a higher early peak in LH secretion reached puberty earlier, compared with calves with a lower early peak in LH secretion (Evans et al., 1995). In the present study, the peak of the early increase in LH secretion in control calves occurred later than we have seen previously, and puberty occurred later than we have previously reported (Evans et al., 1995). Treatment with Leuprolide acetate further delayed the peak of the early rise in LH secretion and puberty was further delayed in these treated calves compared with control calves. These observations would indicate that both the timing and magnitude of the early rise in LH secretion could be important for the initiation and rate of testicular growth, and development and timing of puberty in bull calves. Some caution needs to be exercised, however, in placing too much emphasis on patterns of mean serum concentrations of LH, FSH and testosterone, based on blood samples taken every other week. Secretion of these hormones is episodic (Evans et al, 1993), and the early increase in secretion in the bull calf is due to an increase in pulse frequency and amplitude (Evans et al., 1993). Mean hormone concentrations based on periods of multiple blood sampling, as in the present study, will more accurately reflect a true mean than estimates based on single samples taken every other week; however, the mean hormone concentrations based on single samples collected every other week did give us an indication of the temporal patterns of serum hormone concentrations during development of the bull calves.

The early rise in gonadotrophin secretion in bull calves may be important for the initiation of testicular growth and development (McCarthy et al,, 1979; Amann and Walker, 1983). It occurs just before tubule lumination and differentiation of Sertoli cells and Leydig cells (Curtis and Amann, 1981). Spermatogenesis is initiated during the latter part of the period of the early rise in gonadotrophin secretion (Curtis and Amann, 1981), and rapid growth of the testis is seen after 20 weeks of age (Amann and Walker, 1983). Treatment of bull calves with Leuprolide acetate from 6 to 18 weeks of age did not significantly affect body mass but scrotal circumference was decreased and remained lower than in control calves from 22 to 50 weeks of age. Testicular mass in treated calves was lower than in controls at 50 weeks of age.

Decreasing gonadotrophin secretion in bull calves before 20 weeks of age decreased testicular growth in a manner that was not compensated for by 50 weeks of age, even though there was a rebound in gonadotrophin secretion. However, gonadotrophin secretion from 20 weeks of age to puberty is important for sustained testicular growth (Schanbacher, 1981). The 
decrease in testicular growth seen in the present study was reflected in testis ultrasonographic pixel units; units were higher in control calves (whiter images), suggesting less fluid and greater cellular components. However, the decrease in testicular growth was not a function of a decrease in numbers of Sertoli cells or spermatogonia, cells whose differentiation would start during or just after the period of the early rise in gonadotrophin secretion (Curtis and Amann, 1981). The effect of Leuprolide acetate was one of decreasing or delaying spermatogenesis, with particular effects on cells at more advanced stages of spermatogenesis, such as spermatids and pachytene spermatocytes, cell types that develop after the early rise in gonadotrophin secretion (Curtis and Amann, 1981). It is not clear from the present study how decreasing gonadotrophin and testosterone secretion before 20 weeks of age affected stages of spermatogenesis that occurred after this treatment; perhaps spermatogonial division was slowed or Sertoli cell function impaired. It would not appear that numbers of Leydig cells or function were reduced after the period of treatment, since serum testosterone concentrations were similar in treated and control calves at 24 weeks of age.

In summary, treatment of developing bull calves with Leuprolide acetate between 6 and 18 weeks of age decreased gonadotrophin and testosterone secretion and had the long term effect of delaying testicular maturation despite a rebound in gonadotrophin secretion by 24 weeks of age. We conclude that the early increase in gonadotrophin secretion, before 20 weeks of age, is a critical step in the establishment and timing of normal testicular development in bull calves.

The authors thank S. Cook, T. Hegan, D. Waldbillig and L. Kumor for technical help, B. Kerr and his staff for the care and management of the animals and NIDDK and USDA for the provision of reagents for the gonadotrophin assays. This research was supported by the Natural Sciences and Engineering Research Council of Canada. A. C. O. Evans was supported by a graduate scholarship from the University of Saskatchewan.

\section{References}

Abercrombie M (1946) Estimation of nuclear population from microtome section Anatomical Record 94 238-244

Amann RP and Walker OJ (1983) Changes in the pituitary-gonadal axis associated with puberty in Holstein bulls Journal of Animal Science $\mathbf{5 7}$ $433-442$

Amann RP, Wise WE, Glass JD and Nett TM (1986) Prepubertal changes in the hypothalamic-pituitary axis of Holstein bulls Biology of Reproduction $\mathbf{3 4}$ $71-80$

Aravindan GR, Ravindranath N, Gopalkrishnan K and Moudgal NR (I990) DNA flow-cytometric analysis of testicular germ cell populations of the bonnet monkey (Macaca radiata) as a function of sexual maturity Journal of Reproduction and Fertility $\mathbf{8 9} 397-406$

Chandolia RK, Weinbauer GF, Behre HM and Nieschlag E (1991) Evaluation of a peripherally selective antiandrogen (Casodex) as a tool for studying the relationship between testosterone and spermatogenesis Joumal of Steroid Biochemistry and Molecular Biology 38 367-375

Curtis SK and Amann RP (1981) Testicular development and establishment of spermatogenesis in Holstein bulls Journal of Animal Science 53 1645-1657

Deaver DR and Peters JL (1988) Age-related changes in secretion of luteinizing hormone and metabolism of hypothalamic amines in bull calves prior to puberty Biology of Reproduction 39622-629
Deaver DR, Glass JD, Grieger DM and Reeves J\} (I988) Effects of estradiol on secretion of LH, hypothalamic function and testicular development in bull calves Domestic Animal Endocrinology 54 307-316

Evans ACO and Rawlings NC (1994) Effects of a long-acting gonadotrophinreleasing hormone agonist (Leuprolide) on ovarian follicular development in prepubertal heifer calves Canadian Journal of Animal Science 74 649-656

Evans ACO, Currie WD and Rawlings NC (1993) Opioidergic regulation of gonadotrophin secretion in the early prepubertal bull calf Journal of Reproduction and Fertility 99 45-51

Evans ACO, Davis FJ, Nasser LF, Bowman P and Rawlings NC (1995) Differences in early patterns of gonadotrophin secretion between early and late maturing bulls, and changes in semen characteristics at puberty Theriogenology 43 569-578

Filicori $\mathbf{M}$ and Flamigni $\mathbf{C}(1988) \mathrm{GnRH}$ antagonists and agonists Current Clinical Status of Drugs $3563-82$

Kolho KL, Nikula H and Huhtaniemi I (1987) Sexual maturation of male rats treated postnatally with a gonadotrophin-releasing hormone antagonist Journal of Endocrinology 116 241-246

Lunstra DD, Ford JJ and Echterncamp SE (1978) Puberty in beef bulls: hormone concentrations, growth, testicular development, sperm production and sexual aggressiveness in bulls of different breeds Journal of Animal Science 46 1054-1062

McCarthy MS, Hafs HD and Convey EM (1979) Serum hormone patterns associated with growth and sexual development in bull calves journal of Animal Science 49 1012-1020

MacMillan KL and Hafs HD (1969) The reproductive tract of Holstein bulls from birth through puberty Journal of Animal Science 28 233-239

Medhamurthy R, Aravindan GR and Moudgal NR (1993) Hemiorchidectomy leads to dramatic and immediate alterations in pituitary follicle-stimulating hormone secretion and the functional activity of the remaining testis in the adult male bonnet monkey (Macaca radiata) Biology of Reproduction $\mathbf{4 9}$ 743-749

Merriam GR and Wachter KW (1982) Algorithms for the study of episodic hormone secretion American Journal of Physiology 243 E310-E318

Miyamoto A, Umezu M, Ishii S, Furusawa T, Masaki J, Hasegawa Y and Ohata M (1989) Serum inhibin, FSH, LH and testosterone levels and testicular inhibin content in beef bulls from birth to puberty Animal Reproduction Science 20 165-178

Pechman RD and Eilts BE (1987) B-mode ultrasonography of the bull testicle Theriogenology 27 431-441

Pierson RA and Adams GP (1995) Computer-assisted image analysis, diagnostic ultrasonography and ovulation induction: strange bed fellows Theriogenology $43 \quad 105-112$

Rawlings NC and Evans ACO (1995) Androgen feedback during the early rise in LH secretion in bull calves Journal of Endocrinology $145243-249$

Rawlings NC, Hafs HD and Swanson LV (1972) Testicular and blood plasma androgens in Holstein bulls from birth through puberty Journal of Animal Science 34 435-440

Rawlings NC, Fletcher PW, Henricks DM and Hill JR (1978) Plasma luteinizing hormone $(\mathrm{LH})$ and testosterone levels during sexual maturation in beef bull calves Biology of Reproduction 19 1108-1112

Russel LD and Clermont $Y$ (1977) Degeneration of germ cells in normal, hypophysectomized and hormone treated hypophysectomized rats Anatomical Record 187 347-366

Schanbacher BD (1981) Importance of the episodic nature of luteinizing hormone secretion for normal development of the bovine testis during puberty: interference with oestradiol-17ß Journal of Endocrinology 33 393400

Toppari J, Tsutsumi I, Bishop PC, Parker JW, Ahmed N, Tsang C, Campeau JD and di Zerega GS (1989) Flow cytometric quantitation of rat spermatogenic cells after hypophysectomy and gonadotrophin treatment Biology of Reproduction 40 623-634

Watanabe Y, Nozaki M, Nakamura G, Sano M, Matsuguchi $H$ and Nakano $H$ (1992) Efficiency of a low-dose Leuprolide acetate depot in the treatment of uterine leiomyomata in Japanese woman Fertility and Sterility $\mathbf{5 8} 66-71$

Wilson PR and Lapwood KR (1979) Studies of reproductive development in Romney rams. 1. Basal levels and plasma profiles of LH, testosterone and prolactin Biology of Reproduction 20 965-970

Wolf FR, Almquist JO and Hale EB (1965) Pubertal behavior and pubertal characteristics of beef buils on a high nutrition allowance Journal of Animal Science $24761-765$ 